\title{
VALIDITAS LKPD BERBASIS RME UNTUK SISWA SEKOLAH DASAR
}

\author{
Kurnia Puspita Sari, Taufina \\ Surel: kurniapuspitasari248@gmail.com
}

\begin{abstract}
This study aims to see the validity of LKPD with the RME approach for fifth grade elementary school students using a questionnaire instrument. This research uses the development research method. With fifth grade students at SDN 55 Air Pacah as research subjects. This RME-based LKPD was developed using three-D models covering the stages of defining, designing and developing. The research data was obtained through a validation sheet filled out by several experts on the aspects of didactic, content, language and appearance. Based on the data analysis, it is known that the mathematics learning LKPD with the RME approach for fifth grade elementary school students is considered valid with an average percentage of $85.4 \%$.
\end{abstract}

Keywords: Development, LKPD, Mathematics, RME

\begin{abstract}
ABSTRAK
Penelitian ini bertujuan untuk melihat validitas LKPD dengan pendekatan RME untuk siswa kelas V SD dengan menggunakan instrumen angket. Penelitian ini menggunakan metode penelitian pengembangan. Dengan siswa kelas V SDN 55 Air Pacah sebagai subjek penelitian. LKPD berbasis RME ini dikembangkan dengan menggunakan three- $D$ models meliputi tahap pendefinisian, perancangan dan pengembangan. Data hasil penelitian diperoleh melalui lembar validasi yang diisi oleh beberapa orang pakar pada aspek didaktik, isi, bahasa dan tampilan. Berdasarkan analisis data yang dilakukan diketahui bahwa LKPD pembelajaran matematika dengan pendekatan RME untuk siswa kelas V SD ini dikategorikan valid dengan rata-rata persentase $85,4 \%$.
\end{abstract}

Kata kunci: Pengembangan, LKPD, Matematika, RME

\section{PENDAHULUAN}

Peningkatan mutu sumber daya manusia dapat terealisasi melalui pendidikan. Syafril (2012), tujuan pendidikan yang hendak dicapai yaitu proses kedewasaan jasmani dan rohaniah. Kedewasaan dalam artian terjadinya pertumbuhan dan perkembangan fisik hingga ia berkemampuan dan nantinya sanggup melaksanakan tugas hidup berdasarkan aturan yang berlaku di masyarakat dan bertanggung jawab atas perilakunya sendiri. Proses pembelajaran adalah proses belajar serta mengajar yang merupakan satu kesatuan terintegrasi dan saling mempengaruhi satu dengan yang lain. Pendidikan yaitu salah satu proses peserta didik dimungkinkan dapat berkembang dengan kemampuan yang dimilikinya tanpa paksaan, kehendak orang dewasa baik guru atau orang tua. Dengan adanya pendidikan diharapkan dapat mengupayakan kondisi yang kondusif bagi pertumbuhan anak untuk mengembangkan potensi yang dimilikinya. Salah satu mata pelajaran yang memiliki peran penting dalam 
kehidupan yaitu matematika, terutama untuk mengembangkan kemampuan berpikir kiritis, kreatif dan inovatif. Matematika juga merupakan mata pelajaran penentu kelulusan siswa di suatu jenjang pendidikan. Oleh sebab itu, hendaknya siswa termotivasi dalam mempelajarinya.

Pada kenyataannya mata pelajaran ini diyakini sebagai suatu hal yang sulit serta siswa tidak tertarik dalam mempelajarinya. Pemberian pengalaman langsung kepada siswa dalam pembelajaran matematika sangat penting untuk diterapkan. Pengalaman tersebut akan membentuk pemahaman konsep yang optimal. Yang demikian akan terwujud jika disertai oleh sumber belajar yang memadai. Dapat disimpulkan bahwasanya sumber belajar yang tepat menjadi poin penting dalam memberikan pengalaman langsung kepada siswa untuk membantu siswa memahami materi dengan baik.

Salah satu sumber belajar yang memberikan pengalaman belajar langsung kepada siswa yang membuat ia paham akan materi yang dipelajarinya yaitu menggunakan lembar kerja peserta didik (LKPD). Menurut Munandar (2015) rancangan LKPD yang tepat sangat diperlukan agar proses pembelajaran yang melibatkan peserta didik secara aktif dapat terwujud. Sedangkan menurut Syarifah (2017), Lembar Kerja Peserta Didik (LKPD) adalah beberapa halaman yang isinya berkaitan dengan pertanyaan yang akan dikerjakan oleh peserta didik di dalamnya dilengkapi pedoman dan tahapan kerja yang sifatnya praktik.

Berkaitan dengan hal tersebut LKPD yaitu lembaran kerja baik berbentuk pertanyaan ataupun perintah dari pendidik ke peserta didik untuk mengerjakan suatu aktivitas sifatnya menemukan konsep dan memecahkan masalah, aktivitasnya dapat berupa percobaan/ kerja praktek. Dengan demikian dapat disimpulkan bahwa pembelajaran disertai LKPD akan membuat peserta didik mendapatkan pengalaman langsung untuk memahami konsep matematika sehingga dapat membantu ia memahami matematika dengan baik.

Berdasarkan pengamatan pembelajaran yang dilaksanakan di sekolah didapatkan informasi bahwa guru dalam proses mengajar langsung memberikan rumus kepada siswa kemudian dilanjutkan dengan memberikan latihan. Terkadang guru menggunakan metode kelompok/ diskusi dalam proses pembelajaran.

Berkaitan dengan hasil pengamatan yang ditemui, maka proses pembelajaran yang selama ini dilaksanakan hanya menjadikan siswa sebagai objek dari pembelajaran bukan subjek pembelajaran. Seharusnya siswa dijadikan subjek pembelajaran agar siswa terlibat aktif dalam memahami konsep sehingga memudahkan ia dalam mengingat materi dan menggunakan rumus serta mengaplikasikannya dalam kehidupan sehari-hari.

Berdasarkan observasi terhadap sumber, didapatkan informasi bahwa 
sumber yang digunakan diawali dengan rumus/konsep matematika dan tidak diawali dengan beberapa aktivitas penemuan rumus. Sehingga sumber yang ada belum mampu mengembangkan kemampuan peserta didik secara optimal. Kemudian pembelajaran yang dilaksanakan guru juga terfokus seperti yang tertera pada buku.

Berkaitan dengan permasalahan di atas, maka perlu dikembangkan suatu perangkat pembelajaran yang membantu guru untuk merangcang pembelajaran yang melibatkan siswa secara aktif dan membantu siswa dalam memahami konsep yang mampu mengembangkan kompetensinya secara optimal. Dalam merangcang perangkat tersebut dibutuhkan suatu pendekatan pembelajaran. Salah satu pendekatan yang tepat untuk dipakai yaitu pendekatan RME.

Menurut Jarmita

Realistic Mathematics Education (RME) yaitu suatu pendekatan yang berorientasi kepada hal-hal yang nyata bagi siswa, memfokuskan kepada kegiatan diskusi, bekerjasama, berargumentasi dengan temannya, memecahkan masalah dengan cara mereka sendiri sehingga ia dapat menemukan sendiri suatu konsep tersebut. Jika ia memahami konsep dengan baik, mereka dapat mengaplikasikannya dalam kehidupan sehari-hari. Menurut Supardi (2012) dijenjang pendidikan dasar tepat jika digunakan pendekatan RME.

Oleh sebab itu, karena pentingnya memahami suatu konsep matematika bagi peserta didik. Maka perlu dikembangkan sumber belajar yang dapat memberi pengalaman belajar langsung kepada peserta didik salah satunya dengan mengembangkan LKPD berbasis RME. Untuk itu penulis tertarik untuk melihat kevalidan dari LKPD berbasis RME. Tujuan pembahasan ini adalah menghasilkan LKPD berbasis RME yang valid untuk diterapkan di sekolah.

\section{METODE PENELITIAN}

Penelitian ini digolongkan pada penelitian pengembangan yaitu melalui suatu prosedur ilmiah untuk mengembangkan suatu produk tertentu (Suandi, 2016).

Penelitian ini menggunakan model pengembangan deskriptif dengan jenis pengembangan 3-D. Menurut Trianto (2013) gambaran penelitian ini meliputi tahap define, design dan develop. Uji coba dilakukan pada siswa kelas V SDN 55 Air Pacah. Subjek uji cobanya diambil satu kelas sebanyak 24 orang.

Data yang digunakan dalam penelitin ini yaitu data primer, data yang langsung diperoleh dari beberapa orang pakar melalui lembar validasi. Instrumen penelitian berupa angket pengujian validitas. Angket validitas diisi oleh pakar yang bertujuan untuk menyempurnakan produk yang telah dirancang agar dapat diterapkan di sekolah dengan optimal. Analisis deskriptif kualitatif dan kuantitatif dijadikan teknik analisis data dalam penelitian ini. Deskriptif kualitatif bertujuan 
$\begin{array}{lcr}\text { menjelaskan } & \text { produk } & \text { yang } \\ \text { dikembangkan. } & \text { Sedangkan } & \text { data } \\ \text { kuantitatif } & \text { berkaitan } & \text { dengan } \\ \text { kevalidan produk yang dikembangkan. }\end{array}$

\section{HASIL PENELITIAN DAN PEMBAHASAN}

Sebelum merancang LKPD pembelajaran matematika berbasis RME terlebih dahulu dilakukan analisis kurikulum. Hal tersebut berkaitan dengan analisis indikator, kompetensi inti, kompetensi dasar serta materi pembelajaran. Pada sekolah tempat penelitian berlangsung kurikulum yang digunakan yaitu kurikulum 2013.

Analisis kebutuhan difokuskan pada analisis permasalahan yang terdapat pada perangkat pembelajaran yang telah ada seperti buku siswa, LKPD dan sumber lainnya yang dipakai oleh guru dan siswa. Hasil analisis menggambarkan bahwa perangkat pembelajaran yang dipakai guru belum menempatkan siswa sebagai subjek pembelajaran, sehingga siswa hanya bersikap menerima ilmu yang diberikan guru.

Analisis ini dijadikan sebagai gambaran untuk mengembangkan LKPD. Meliputi usia, gambaran sosial, serta kecendrungan model belajar dan potensi dasar siswa SD. Pada penelitian ini, siswa kelas V SDN 55 Air Pacah dijadikan sebagai subjek penelitian yang berusia 11-12 tahun. Pada kategori ini, siswa sudah berada pada level perkembangan intelektual operasional konkrit, pada level ini pemikiran siswa berkembang dengan cepat, ia telah bisa menalarkan suatu hal serta dari segi psikomotornya ia telah mampu menggunakan suatu alat peraga dengan baik terlebih menggunakan sumber belajar berupa LKPD.

Hasil yang didapat setelah melakukan analisis kebutuhan, digunakan untuk merancang LKPD berbasis Realistics Mathematics Education (RME). Rancangan dari LKPD berbasis Realistics Mathematics Education (RME) ini, terdiri dari beberapa komponen yaitu sampul/cover, kata pengantar, daftar isi, deskripsi singkat mengenai LKPD berbasis RME, SK, KD, indikator dan tujuan pembelajaran, kegiatan pembelajaran dan soal latihan. Kegiatan pembelajaran dalam LKPD terdiri dari dua kegiatan pembelajaran. Pada pembelajaran1 memuat materi volum kubus dan pembelajaran 2 memuat materi volum balok.

Kegiatan pembelajaran pada LKPD ini, dibuat dan disusun berdasarkan silabus, materi serta karakteristik dari Realistics Mathematics Education. Berbentuk aktivitas-aktivitas untuk menemukan konsep volum kubus dan balok, sebelumnya diberikan ilustrasi sebagai pengantar untuk melaksanakan aktivitas. Dilanjutkan dengan soal latihan yang diadopsi dari buku-buku pelajaran matematika kelas V.

Data validitas diperoleh dengan menggunakan angket validitas. Uji validitas bertujuan untuk memeriksa kecocokan produk dengan kurikulum yang berlaku, keakuratan konsep, bentuk serta tampilan produk. 
Validitas tersebut dilaksanakan beberapa ahli berkaitan dengan cakupan kompetensinya. Masukan dari validator dijadikan pertimbangan untuk mengevaluasi dan merevisi produk berupa LKPD berbasis Realistics Mathematics Education.

Berikut ini beberapa aspek yang dilihat pada lembar validasi LKPD sebagai berikut:

Tabel 1. Validasi LKPD

\begin{tabular}{l|l|l|l}
\hline No & Aspek & $\begin{array}{l}\text { Bentuk } \\
\text { Pengumpulan } \\
\text { Data }\end{array}$ & Alat \\
\cline { 1 - 2 } 1. & Didaktik & $\begin{array}{l}\text { Memberikan } \\
\text { lembar } \\
\text { validasi ke } \\
\text { beberapa } \\
\text { orang dosen. }\end{array}$ & $\begin{array}{l}\text { Lembar } \\
\text { validasi }\end{array}$ \\
\cline { 1 - 2 } 2. & Isi & Bahasa & \\
\cline { 1 - 2 } 3. & Tampilan & & \\
\hline
\end{tabular}

Berdasarkan aspek tersebut, kemudian LKPD yang telah disusun di validasi oleh validator yang sesuai dengan bidang kajiannya. LKPD Berbasis Realistic Mathematics Education divalidasi oleh 4 orang ahli. Pada tahapan pengembangan LKPD, sebelumnya LKPD tersebut diberikan kepada validator kemudian ada beberapa kali perubahan sesuai dengan masukan dari ahlinya. Setelah LKPD melalui tahapan revisi dan validasi oleh validator maka diperoleh hasil validasi LKPD yang dilakukan oleh empat validator.

\section{Pembahasan}

Berdasarkan hasil analisis dari validasi LKPD Berbasis Realistic
Mathematics Education yang dinilai oleh validator baik dari aspek didaktik, isi, bahasa dan tampilan adalah 85,4\% dapat diartikan LKPD yang dikembangkan dikategorikan valid. Dari aspek didaktik 90,6\% dikategorikan sangat valid, aspek isi 90\% dikategorikan sangat valid, aspek bahasa $80 \%$ masuk kriteria valid dan aspek tampilan 81,2\% dikategorikan valid.

Berdasarkan analisis data yang dipaparkan di atas, diperoleh informasi bahwasanya LKPD yang dikembangkan termasuk kategori valid. Sehingga dapat diberikan kepada siswa di sekolah. Dimungkinkan dengan adanya LKPD tersebut memberikan alternatif sumber belajar yang tepat untuk membantu siswa memahami konsep matematika terutama bagi siswa kelas V SD.

\section{SIMPULAN}

Berkaitan dengan analisis data yang telah dipaparkan sebelumnya, disimpulkan bahwa kevalidan LKPD berbasis Realistic Mathematics Education untuk kelas V SD yang telah dikembangkan kategori valid dengan rata-rata persentase kevalidan $85,4 \%$, dimaknai bahwa LKPD berbasis Realistic Mathematics Education valid dan dapat digunakan untuk mengukur apa yang seharusnya diukur. Dari aspek didaktik diperoleh persentase kevalidannya $90,6 \%$, isi $90 \%$, bahasa $80 \%$, dan tampilan $81,2 \%$.

Sehingga dengan demikian dapat disimpulkan LKPD 
pembelajaran matematika berbasis RME untuk kelas V SD yang telah dikembangkan dengan menggunakan instrumen lembar validasi dikatategorikan valid sehingga bisa diterapkan dalam pembelajaran di sekolah.

\section{DAFTAR RUJUKAN}

Jarmita, Nida. 2013. Ketuntasan Hasil Belajar Siswa Melalui Pendekatan Realistic Mathematics Education (RME) Pada Materi Perkalian. Jurnal Ilmiah DIDAKTIKA. Vol 13, No 2, Hal: 212-222.

Munandar, Haris. 2015. Pengembangan Lembar Kerja Peserta Didik (LKPD) Berorientasi Nilai Islami Pada Materi Hidrolisis Garam. Jurnal Pendidikan Sains Indonesia. Vol 3, No 1, Hal 27-37.

Suandi, D. 2016. Pedoman Penulisan Karya Ilmiah. Singaraja: Universitas Pendidikan Ganesha.

Supardi. 2012. Pengaruh Pembelajaran Matematika Realistik Terhadap Hasil Belajar Matematika Ditinjau dari Motivasi Belajar. Jurnal Cakrawala Pendidikan. Vol 2, Nomor 2, Hal 244-255.

Syafril, Zelhendri Zen. 2012. Pengantar Pendidikan. Padang: Sukabina Press.

Syarifah, Siti. 2017. Pengembangan Lembar Kerja Peserta Didik (LKPD) Berorientasi Nilai-nilai Agama Islam Melalui Pendekatan Inkuiri Terbimbing Materi Trigonometri. dalam
Skripsi. Fakultas Tarbiyah dan Keguruan. Universitas Islam Negeri Raden Intan.

Trianto. 2013. Mendesain Model Pembelajaran Inovatif-Progresif. Jakarta: Kencana Prenamedia Group. 